\title{
DYNAMICS OF SERUM PROTEIN DURING THE ESTROUS CYCLE OF GOATS BRED IN BRAZIL AND NATURALLY INFECTED BY CAPRINE ARTHRITIS EN CEPHALITIS VIRUS
}

\author{
F.C. Cyrillo, M.L. do R. Leal, F.J. Benesi, A.M.M. de P. Della Libera
}

UniversidadedeSão Paulo, Faculdadede M edicina Veterinária eZootecnia, Departamento deClínica Médica, Av. Prof. Dr. Orlando Marques de Paiva, 87, CEP 05508-900, São Paulo, SP, Brazil.

\begin{abstract}
The aim of the present study was to evaluate variations in proteinogram occurring during theestruscycleof animal sinfected or not by caprinearthritisencephal itis. Forty blood samples were collected from female goats in different phases of the estrus cycle (estrus, proestrus, metaestrus and diestrus). Samples were classified as positive $(n=5)$ and negative $(n=5)$, according to the results of the survey of antibodies against caprine arthritis encephalitis as performed by immunodiffusion in agar gel. Samples were also used in the determination of al bumin, total protein and alpha, beta and gammaglobulin by means of electrophoresis and biuret method, respectively. Electrophoresis showed that estrus, proestrus, metaestrus and diestruspositiveanimal spresented total protein mean equal to $7.96 \pm 0.69,7.67 \pm 1.14,7.77 \pm 0.36$, $7.48 \pm 0.83$; mean albumin equal to $3.22 \pm 0.41,3.11 \pm 0.68,3.30 \pm 0.67,3.28 \pm 0.57$; mean al phagl obulin equal to $0.70 \pm 0.09,0.70 \pm 0.12,0.69 \pm 0.12,0.61 \pm 0.11$; mean betagl obulin 1 equal to $0.85 \pm 0.04,0.87 \pm 0.04,0.90 \pm 0.12,0.83 \pm 0.11$; mean betaglobulin 2 equal to $0.77 \pm 0.18,0.68$ $\pm 0.17,0.60 \pm 0.15,0.54 \pm 0.09$; and mean gammagl obulin equal to $2.43 \pm 0.47,2.31 \pm 0.54,2.28 \pm$ $0.49,2.21 \pm 0.54$. N egativeanimal spresented mean total protein equal $7.76 \pm 1.31,8.03 \pm 1.10,7.50$ $\pm 0.51,6.49 \pm 1.14$; mean albumin equal to $3.06 \pm 0.46,3.19 \pm 0.46,3.03 \pm 0.62,2.93 \pm 0.96$; mean al phagl obulin equal to $0.69 \pm 0.19,0.75 \pm 0.18,0.70 \pm 0.24,0.58 \pm 0.20$; mean betagl obulin 1 equal to $0.79 \pm 0.03,0.79 \pm 0.23,0.80 \pm 0.15,0.66 \pm 0.16$; mean betaglobulin 2 equal to $0.67 \pm 0.20,0.95$ $\pm 0.37,0.81 \pm 0.40,0.73 \pm 0.41$; and mean gammagl obulin equal to $2.35 \pm 1.42 ; 2.42 \pm 1.30,2.23 \pm$ $1.03,1.92 \pm 0.70$, respectively. Variance analysis did not show any statistically significant differences. A nimals infected by caprinearthritisencephalitis (CAE) did not present any changes in proteinogram, regardless of the phase of the estrus cyclethey were in.
\end{abstract}

KEY WORDS: Goats, estrus cycle, CAEV, serum protein.

\section{RESUMO}

DINÂMICASDA PROTEÍNA SÉRICA DURANTEO CICLOESTRAL DE CABRASCRIADASNO BRASILENATURALMENTEINFECTADOSPELA ARTRITEEN CEFÁLICA CAPRINA.O presente trabal hotevecomobjetivo aval iar variações ocorridas duranteo cicl oestral no proteinogramaem animaisinfectadospelaartriteencefal itecaprina. Foramcoletadas40amostras desanguedecabras, nasdiferentesfases do ciclo estral (estro, proestro, metaestro ediestro), asquai sforam classificadas como positivas $(n=5)$ enegativas $(n=5)$, deacordo como resul tado da pesquisadeanticorposcontra o vírus da artrite encefal ite caprina realizada pela prova de imunodifusão em gel de ágar. Nas amostras foram determinadas as concentrações de albumina, alfaglobulina, betaglobulina e gamagl obulinaedosagem deproteínas totais pel os métodos deel etroforeseebiureto respectivamente. As anál ises eletroforéticas, realizadas, estro, proestro, metaestro eno diestro, os animais positivos apresentaram média de 7,96 $\pm 0,69,7,67 \pm 1,14,7,77 \pm 0,36,7,48 \pm 0,83$ de proteína total, média de $3,22 \pm 0,41,3,11 \pm 0,68,3,30 \pm 0,67,3,28 \pm 0,57$ deal bumina, média de $0,70 \pm 0,09,0,70 \pm 0,12$, $0,69 \pm 0,12,0,61 \pm 0,11$ de al fagl obul ina, média de $0,85 \pm 0,04,0,87 \pm 0,04,0,90 \pm 0,12,0,83 \pm 0,11$ de betaglobulina1, média de $0,77 \pm 0,18,0,68 \pm 0,17,0,60 \pm 0,15 ; 0,54 \pm 0,09$ de betagl obulina2 emédia de 2,43 $\pm 0,47,2,31 \pm 0,54,2,28 \pm 0,49,2,21 \pm 0,54$ de gamaglobulina e os animais negativos apresentaram média de 7,76 $\pm 1,31,8,03 \pm 1,10,7,50 \pm 0,51,6,49 \pm 1,14$ de proteína total; média de $3,06 \pm 0,46 ; 3,19 \pm 0,46 ; 3,03 \pm 0,62 ; 2,93 \pm 0,96$ deal bumi na; média de 0,69 $\pm 0,19,0,75 \pm 0,18,0,70 \pm 0,24$, $0,58 \pm 0,20$ dealfagl obulina; médiade $0,79 \pm 0,03,0,79 \pm 0,23,0,80 \pm 0,15,0,66 \pm 0,16$ debetaglobulinal; média de 0,67 $\pm 0,20,0,95 \pm 0,37,0,81 \pm 0,40,0,73 \pm 0,41$ de betagl obulina2; e média de 2,35 $\pm 1,42$, $2,42 \pm 1,30,2,23 \pm 1,03,1,92 \pm 0,70$ de gamaglobulina, respectivamente. $N$ ão foram encontradas diferenças estatísticas significantes na análise de variância. Os animais infectados pela artrite 
encefalitecaprina(CAE) não apresentamalterações no proteinogramaindependentementedafase do ciclo estral em que se encontravam.

PALAVRA-CHAVE:Caprinos, cliclo estral, CAE, proteína sérica.

\section{INTRODUCTION}

Caprine arthritis encephalitis (CAEV) is caused by a virus of the family Retroviridae, subfamily Orthor etrovirinae, genus Lentivirus (BUCHEN-OSMOND, 2004). It is a single-stranded virus that replicates by means of the production of deoxyribonucleic acid (DNA), and depends on intermediate reverse transcriptase. Thiskind of virus may insertits genetic material in the genome of the host (PuGH, 2002).

The virus enters monocytes and macrophages, inducing persistent infection. Restricted replication enables the virus to remain latent in monocytes, undetected by the host immune system, leading to many debilitating, severe, progressive diseases. The virusquickly replicatesin thebeginning of theinfection, activating theimmunesystem, which limits, but does notel iminatethevirus. Infected macrophagesexpress viral proteins similar to the antigens of the main histocompatibility complex, which arerecognized by $\mathrm{T}$ lymphocytes and stimulate the production of cytokines. These macrophages may be more susceptible to activation, inducing lymphocyte and macrophage proliferation. Lymphocyteproliferation determines thepathological changes characteristic of CAE infection. Transmission routes reported are the ingestion of milk or colostrum from an infected dam, and horizontal transmission after a long period of contact. The virus preferentially affects joints, mammary gland, lungsand brain, wheretheimmune system of the host tends to manifest chronic inflammation (Bohland \& D'Angelino, 1999; Pugh, 2002).

CAE is oneof thediseasesmostresponsiblefor the limitation to the development of productive goat breeding in São Paulo and in Brazil. In 2003, the Brazilian herd was constituted of 9,581,653 head (Instituto Brasileiro de Geografia e Estatistica, 2004). Prevalencerates of the disease show that the agent is disseminated throughout thecountry, as an enzootic disease that is present in most of the geo-economic regionsand herds. CAE leadsto importantlosses, due tothediscard of prematurekids, mortality and decrease in productivity (BOHLAND, 1998).

Some organic changes or even theintensity of the inflammatory response may be influenced by the phase of the estrus cycle in which the animal is (HAENLEIN, 2002). The hypothesis that this phenomenon is even greater influenced by the occurrenceof chronicdiseasessuch as CA E should be further studied.
The estrus cycle of female goat lasts 21 days, in average. Its phases, proestrus, estrus, metaestrus and diestrus, last, respectively, 2 to 3 days, 30 to 40 hours, 2 to 3 days and 13 to 15 days (RAPoso, et al., 1999). These phases occur in a cyclic and sequential manner, except for anestrus, which has to be considered in this species, for goats are seasonal polyestrous animals.

Dueto the biological meaning (KANEKO,1997) and multiple functions of proteins in the body (such as being part of the cell structure, tissues, organs, hormones, enzymatic catalysts, antibodies, and others), theevaluation of serumlevel sof total proteins and their fractions (albumin, alphaglobulin, betagal obulin 1, betagl obulin 2and gammaglobulin), as detected by electrophoresis, and the influence caused by theestruscycleand/ orchronic,multisystemic diseases (BIRGEL Junior et al., 2001; Garcia etal., 2002), such as caprinearthritisencephalitis, isan important tool aiding clinical diagnosis.

The objective of the present study was to evaluate the dynamics of serum proteins during the estrus cycleoffemalegoatsaffected and unaffected by caprine arthritis encephalitis.

\section{MATERIAL AND METHOD}

Thisstudy used 10 femaleSaanen and Toggenburg femalegoats bred in an intensivesystem and fed goat food, hay and mineral supplement.

These animals were separated into two groups according to their status as determined by immunodiffusion in agar gel antibodies against caprinearthritisencephalitisvirus (CutLIP etal.,1977).

For the evaluation of serum protein dynamics, blood samples were collected by a puncture in the external jugular vein, with $10 \mathrm{~mL}$ Vacutainer tubes. They werecentrifuged for 15 minutes and serum was separated and fractionated in two aliquots stored at $-20^{\circ} \mathrm{C}$ until they were to be analyzed.

Total proteins were quantified in an automatic biochemical analyzerusingthebiuretmethod (KANEKO, 1997). Electrophoresis fractioning of serum proteins was performed in cellulose acetate strips, according to the techniques described by Friedman (1961).

Data on the determination of total protein and its fractions by means of electrophoresis (albumin, al phaglobulin, betaglobulin 1, betaglobulin 2 and gammaglobulin) weresubmitted to varianceanalysis (ANOVA) and to the Student N ewman-Keuls test to 
compare pair of means at a $5 \%$ significancelevel ( $\alpha=$ 0.05).

Statistical analyses were performed by means of the Graphpad Instat software.

\section{RESULTS}

Valuesobserved for the different protein fractions of adultgoats positiveor negativefor caprinearthritis encephalitis were inside the normal range expected for the species and age (BIRGEL \& Araújo, 1968).

Resultsobtained inthepresentstudy arepresented inTableland noinfluenceof theperiod of estruscycle was detected.

\section{DISCUSSION}

Interference of retrovirosis in humoral immune responses have been studied in other species (BIRGEL JUNIOR et al., 2001; GARCIA et al., 2002), mainly in relation to enzootic bovine leucosis (EBL). These authors studied the dynamics of serum proteins not only as markers of acuteinflammatory process, but also as an indirect way to evaluate humoral response.

BOHLAND \& D'ANGELINO (1999) described theclinical and epidemiological aspects of caprine arthritis encephalitis and its importance to Brazilian goat breeding. They did not identify any information on the variations observed with the estrus cycle.

The phenomenon observed in the present study has been partially described in bovines affected by EBL, which is also a multisystemic retrovirosis of chronic evolution, in which proteinogram presented no differences between positiveand negativeanimals (GARCIA et al., 2002), although the interference of the estruscyclewasnotbeen evaluated by thoseauthors. No differences were observed in the dynamics of proteins and fractionsattributable to the estrus cycle and/ or caprine arthritis encephalitis.

References

BirgelJúnior, E.H.;Salvatore,L.C.A.;N eves,F.S.;M IRAndola, R.M. S.; SouzA, P. M.; BIRGEL, E.H. Dinâmica das proteínas séricas de fêmeas bovinas da raça holandesa natural mente infectadas pelo vírus da leucose dos bovinos. Ciência Rural, v.31, n.4, p.615-619, 2001.

BirgeL, E.H. \& A raújo, L.M. Quadro protéico defêmeas da espéciecaprina (caprahircus), criadasnoEstado deSão Paulo. Revista da Faculdade deM edicina eV eterinária de São Paulo, v.7, n.4, p.953-968, 1968.

BoHLAND, E. A rtrite encefalite caprina: avaliação dos aspectos produtivos e reprodutivos de animais infectados e não infectados. 1998. 95f. Dissertação (M estrado em clínica




Veterinária) - Faculdade de M edicina Veterinária e Zootecnia, UniversidadedeSãoPaulo, São Paulo,1998.

BohlAND, E. \& D'ANGELINo, J.L. Artrite encefal ite caprinaaspectos clíni cos eepidemiológi cos. R evista deE ducação Continuada do CRM V-SP, v.2, n.2, p.4-8, 1999.

Buchen-Osmond, C 00.061.1.06.007. Caprine arthritis encephalitis virus. In: Buchen-Osmond, C (Ed.). The universal virus. D atabase, version 3. ICTV dB management. New York: Columbia university, 2004.

CUTLIP, R.C.;] ACKSON , T.A.; LAIRD, G.A. Immunodifusion test of ovine progressive pneumonia. A merican Journal of V eteterinary Research, v.38, n.7, p.1081-1084, 1977.

FrIEDMAN , H.S. A standardized procedurefor serum protein el etrophoresis on celul ose acetatemembranestrips. Clínica Chimica A cta, v.6, p.775-781, 1961.

Garcia,M.;Bastos,P.A.S.;Silva,M.M.;M artins, M .F.;LetTrY, $V$. Concentração sérica degamaglobulinas em bovinos naturalmente infectados pelo vírus da leucose enzoótica bovina. A rs V eterinaria, v.18, n.1, p.62-66, 2002.
HAENLEIN, G.F.W. Relationship of somatic cell counts in goatmilk to mastitisand productivity.Small Ruminant Research, n.42, p.163-178, 2002.

Instituto Brasileiro de Geografia e Estatistica. Censo agropecuário. Disponível em: Łttp:/ / www.ibge. gov.br/ ibge/ estatística/ economia/ agropecuária/ censoagro/ default.shtm>. A cesso em: 28 out. 2004.

Kaneko,J.J.; H ARHEY,I.W.; BRUSS, M.L. Clinical biochemistry of domestic an imal, 5.ed. San Diego:A cademicPress, 1997. 932p.

Pugh, D.G. Sheep and goat medicine. Philadelphia: W. B. Saunders, 2002. 468p.

Raposo,R.S.;Silva, L.D.M.;LôBo,R.N.B.;Freitas, V.J.F.;DıAS, F.E.F.Perfil citológicovaginal decabrascíclicasdaraça Saanen. Ciência A nimal, v.9, n.2, p.75-79, 1999.

Received on 2/ 12/ 05 Accepted on 10/ 2/ 06 